\title{
NONLINEAR AGROMETEOROLOGICAL MODELS FOR ESTIMATING LYCHEE FRUIT GROWTH ${ }^{1}$
}

\author{
LUCAS EDUARDO DE OLIVEIRA APARECIDO ${ }^{2}$, RAFAEL BIBIANO FERREIRA ${ }^{3}$, \\ GLAUCO DE SOUZA ROLIM², BIANCA SARZI DE SOUZA ${ }^{4}$, PAULO SERGIO DE SOUZA ${ }^{4}$
}

ABSTRACT- The influence of climate on the development of lychee fruit is complex, but few studies have discussed the problem. We developed agrometeorological models for simulating the development of fruit fresh matter (FM), fruit dry matter (DM), fruit length (LE), fruit diameter (DI), fruit volume (VO), and fruit number per cluster (FN) of the "Bengal" lychee cultivar as functions of climatic conditions. We conducted three analyses: (a) the influence of mean meteorological elements on the rates of fruit growth, (b) estimation of fruit development by the agrometeorological models using sigmoidal adjustments, and (c) simulation of fruit development using multiple nonlinear regression of two meteorological elements to improve the accuracy. A rate of water deficit (WD) near $5 \mathrm{~mm} \mathrm{~d}^{-1}$ maximised FM, DM, LE, DI, and VO. Increases in potential evapotranspiration (PET), degree days (DD), and actual evapotranspiration (AET) were correlated with increases in VO and decreases in LE and NF. Models estimating fruit development indicated that the accumulation of WD, PET, AET, and DD had sigmoidal relationships with all variables of fruit growth except FN. FN decreased as WD, PET, AET, and DD increased. The adjusted multivariate models were accurate, with the largest error of $6.45 \mathrm{~cm}^{3}(\mathrm{VO})$. The best models were: $\mathrm{FM}=\mathrm{f}\left(\sum \mathrm{WD}, \mathrm{DD}\right), \mathrm{LE}=\mathrm{f}\left(\sum \mathrm{AET}, \mathrm{DD}\right), \mathrm{DI}$ $=\mathrm{f}\left(\sum \mathrm{WD}, \mathrm{DD}\right), \mathrm{VO}=\mathrm{f}\left(\sum \mathrm{WD}, \mathrm{DD}\right)$, and $\mathrm{FN}=\mathrm{f}\left(\sum \mathrm{AET}, \mathrm{WD}\right)$.

Index terms: analysis of growth, water deficit, fruit number, climate.

\section{MODELOS AGROMETEOROLÓGICOS NÃO-LINEARES PARA ESTIMAR O DESENVOLVIMENTO DE FRUTOS DE LICHIA}

RESUMO - A influência do clima no desenvolvimento de frutos de lichia é complexa, e poucos trabalhos abordam a questão. Objetivou-se com este trabalho determinar modelos agrometeorológicos para simular o desenvolvimento da matéria fresca (FM), matéria seca (DM), comprimento do fruto (FE), diâmetro do fruto (DI), volume do fruto (VO) e número de frutos (FN) de lichia "bengal". Foram feitas 3 análises distintas: (a) analisaram-se as influências médias dos elementos meteorológicos nas taxas de variações do crescimento dos frutos; (b) estimou-se o desenvolvimento dos frutos por modelos agrometeorológicos, para tanto, empregaram-se modelos de regressões não lineares sigmoidais; (c) também foi simulado o desenvolvimento dos frutos utilizando regressão não linear com duas variáveis climáticas conjuntamente, buscando a melhoria da acurácia. Como resultado, analisando de forma média a influência das taxas de variação dos elementos meteorológicos nas taxas de crescimento dos frutos de lichia, verificou-se que a taxa de déficit hídrico (WD) em torno de $5 \mathrm{~mm}$ maximiza a FM, DM, LE, DI e VO. O aumento da taxa de evapotranspiração potencial (PET), evapotranspiração atual (AET) e graus-dias (DD) diminuem o LE, NF e aumentam o VO. Os modelos ajustados para a estimação dos valores ao longo do desenvolvimento dos frutos mostraram que o acúmulo de WD, PET, AET e DD tem relação sigmoidal em todas as variáveis de crescimento dos frutos, exceto para FN. O FN decresceu com o aumento do WD, PET, AET e DD. Os modelos multivariados ajustados foram acurados, uma vez que o maior erro encontrado foi de 6,45 (cm3) (VO). Os melhores modelos encontrados foram: $F M=f\left(\sum W D, D D\right), L E=f\left(\sum A E T, D D\right), D I=f\left(\sum W D, D D\right), V O=f\left(\sum W D, D D\right)$ e FN $=f\left(\sum A E T, W D\right)$. Termos para indexação: análise de crescimento, déficit hídrico, número de frutos, clima.

\footnotetext{
'(Paper 224-15). Received September 29, 2015. Accepted May 02, 2016.

${ }^{2}$ UNESP - São Paulo State University, Department of Exact Sciences, 14884-900, Jaboticabal-SP, Brazil, Email: lucas-aparecido@ outlook.com; rolim@fcav.unesp.br

${ }^{3}$ UNESP - São Paulo State University, Botucatu-SP. Email: aprigio_bibiano@hotmail.com

${ }^{4}$ IFSULDEMINAS - Campus Muzambinho-MG. Email: bianca.souza@muz.ifsuldeminas.edu.br; paulo.souza@muz.ifsuldeminas. edu.br.
} 


\section{INTRODUCTION}

The lychee (Litchi chinensis Sonn.) is a tropical plant of the Sapindaceae family (KUMAR et al., 2012) originating from China (MENZEL; PAXTON, 1985), and its fruits have high commercial value. India is the largest producer, with yields of approximately 0.5 million $t$ in an area of 62000 ha (PANDEY et al., 2013). Orchards in Brazil are concentrated in the states of São Paulo (SP), Minas Gerais (MG), and Paraná (MARTINS, 2005), but lychee cultivation is not traditional in the country (QUEIROZ et al., 2012).

Climate is the most important variable in agricultural production (WAGNER et al., 2011), because it directly and indirectly influences the crops by regulating the growth, yield, and quality of agricultural products (BRIXNER et al., 2014; KUMAR et al., 2014). Solar irradiance provides the energy for photosynthesis and the partitioning of plant carbohydrates (OLIVEIRA et al., 2012).

Water deficit is a limiting factor (ALBUQUERQUE et al., 2013) that affects the growth and development of crops (SANTOS; CARLESSO, 1998), with effects on diverse physiological processes of plants (PEIXOTO et al., 2006), and thermal conditions influence phenological development (WAGNER et al., 2011; WALTER et al., 2014). Air temperatures $<11^{\circ} \mathrm{C}$ stop lychee growth, and the crop has high vegetative growth in hot regions, reducing the formation of flowers and fruits (MENZEL; PAXTON, 1985).

The lychee fruit physiologically matures about 112 days after flowering (SALOMÃO et al., 2006), or after approximately 2.5 months after fruit set (WEI et al., 2013). The development can be expressed as a simple sigmoidal curve with two distinct phases, the first characterised by the growth of the skin and seeds (PEREIRA; MITRA, 2005) and the second by rapid growth of the aril (HIEKE et al., 2002). The fruits grow for about two months until they begin to mature. The fruit is green at this phenological phase and can fall off the tree (SANTOS et al., 2009). This fruit fall is natural and occurs between 35 and 56 days after anthesis (WEI et al., 2013).

The maturation phase begins when the fruit is fully developed and the pericarp begins to change from green to red, until the entire fruit is red (WEI et al., 2013). The fruits, which are not considered climacteric (KUMAR et al., 2012), reach physiological maturity when the pulp becomes translucent and has a juicy texture, the taste is slightly acidic but sweet (DEMBITSKY et al., 2011), the aroma is pleasant, and the colouration is very attractive to the consumer (LIMA et al., 2010). This colouration is due to anthocyanin pigments that are commonly associated with diurnal and nocturnal air temperatures (GAZULA et al., 2005; REUCK et al., 2009).

Models can be used to simulate crop development. For example, Matarazzo et al. (2013) determined a curve for the development of lulo fruit (Solanum quitoense Lam) and found that the pattern of development adjusted to a simple sigmoid model, with three stages of growth. Sigmoidal models were similarly used by Alves et al. (2013) for estimating the development of sweet passionfruit.

Few studies have analysed the influence of climate on lychee development, so the aim of this study was to develop crop models for simulating the development of fresh matter, dry matter, length, diameter, volume and number of fruit per cluster in the "Bengal" lychee cultivar under regional Brazilian conditions.

\section{MATERIALS AND METHODS}

Lychee fruits were collected in two orchards. One orchard was in the region of Monte Belo-MG, $\left(21^{\circ} 19^{\prime} \mathrm{S}, 46^{\circ} 22^{\prime} \mathrm{W} ; 844 \mathrm{~m}\right.$ a.s.l.). The predominant climatic classification of this region following Thornthwaite (1948) is $\mathrm{B}_{4} \mathrm{rB}_{2}$ a. The other orchard was in Casa Branca-SP, $\left(21^{\circ} 47^{\prime} \mathrm{S}, 47^{\circ} 06^{\prime} \mathrm{W}\right.$; $702 \mathrm{~m}$ a.s.1.). The predominant climatic classification of this region following Thornthwaite (1948) is $\mathrm{B}_{2} \mathrm{rB}_{3} \mathrm{a}^{\prime}$ (ROLIM; APARECIDO, 2015). The distance between these two locations, important lychee agricultural areas in Brazil, is approximately $100 \mathrm{~km}$.

The study was conducted from August to December 2013, with evaluations every 15 days. The lychee fruits were submitted to a longitudinal (in time) and hierarchical (fruit within plants in the orchards) study. The fruits were collected from 20 plants (10 plants in each orchard), all with excellent health and in full production. We selected a cluster per plant with 10 fruits. Clusters are groups of fruits of the same age on a plant. The marked clusters had closed flowers for obtaining fruits of the same chronological and physiological age. The first fruits were collected about seven days after anthesis at both locations, and the last were collected 91 and 93 days after anthesis in Casa Branca-SP and Monte Belo$\mathrm{MG}$, respectively, when the fruit reached commercial maturity.

The fruits in the marked clusters were harvested at random, totalling 10 fruits per date at each location. The length (LE, mm), equatorial 
diameter (DI $\mathrm{mm})$, and volume $\left(\mathrm{VO}, \mathrm{cm}^{3}\right)$ of the fruit were evaluated using a digital pachymeter. The number of fruits per inflorescence (FN) were counted, and the fresh (FM, g) and dry (DM, g) matters of the fruit were weighed. DM was weighed after drying to a constant weight in a ventilated oven at $65^{\circ} \mathrm{C}$ (AOAC, 2012). FM and DM were weighed by an analytical balance with a capacity of $1200 \mathrm{~g}$ and a precision of $0.1 \mathrm{~g}$.

We installed an automatic meteorological station at each location. Data for hourly air temperature $\left({ }^{\circ} \mathrm{C}\right)$ and rainfall $(\mathrm{mm})$ were measured by 107-L and TB4-L sensors (Campbell Scientific, Logan, USA), respectively. The data were collected by a Campbell Scientific model $21 \mathrm{X}$ data logger. The sequential monthly water balance (water deficit (WD, $\mathrm{mm}$ ) and actual evapotranspiration (AET, $\mathrm{mm}$ )) was calculated as proposed by Thornthwaite and Mather (1955), using an available-water capacity of $100 \mathrm{~mm}$. The potential evapotranspiration (PET, $\mathrm{mm}$ ) was estimated using the Thornthwaite (1948) method.

We used a lower base temperature of $11^{\circ} \mathrm{C}$, as proposed by Menzel and Paxton (1985). The sum of degree days (DD, ${ }^{\circ} \mathrm{C}$ days) was obtained from flowering to fruit fall:

$$
\sum G D=\left[\frac{T \max -T \min }{2}\right]-\text { Tbase }
$$

where $\sum$ GD is the sum of DD, Tmax is the absolute daily maximum air temperature $\left({ }^{\circ} \mathrm{C}\right)$, Tmin is the absolute daily minimum air temperature $\left({ }^{\circ} \mathrm{C}\right)$, and Tbase is the lower base temperature of cultivation.

The influence of the meteorological elements on the average rates of fruit growth was analysed by regression analysis using quadratic adjustments. The independent variables were WD, PET, AET, and DD, and the dependent variables were FM, DM, LE, fruit diameter $(\mathrm{mm})$, fruit volume $\left(\mathrm{cm}^{3}\right)$ and fruit number per cluster. The rates were calculated as the current date value less the values at the previous day.

For generation of agro-meteorological models for estimating the growth of the fruits using sigmoidal curve adjustments, with three Logistic and four Boltzmann parameters (equations 2 and 3 , respectively) using ordinary least squares, which minimises the sum of the squared errors of the model, using the generalised reduced gradient optimisation system (LASDON; WAREN, 1982):

$$
y=\frac{\alpha}{1+\beta \times \theta^{(-\gamma \times x)}}
$$

$$
y=y_{0}+\frac{\alpha}{1+e^{-\left(\frac{x-x_{0}}{b}\right)}}
$$

where $y$ is the estimated cumulative variable, $\alpha$ is the peak of the curve (amplitude), $\beta$ is an integration constant, $\gamma$ is the efficiency of development, $\mathrm{y}_{0}$ is the lowest point of the curve, $\mathrm{x}_{0}$ is the inflection point, and $b$ is an adjustment parameter.

The models were selected by evaluating the accuracy using the mean absolute percentage error (MAPE, \%), the precision using the adjusted coefficient of determination ( $R^{2} \mathrm{adj}$ ) (CORNELL; BERGER, 1987), and the tendency using the systematic error (ES, same unit as the data), (equations 4, 5, and 6, respectively):

$$
\begin{gathered}
\text { MAPE }=\frac{\sum_{i=1}^{N}\left(\mid \frac{\left.Y e s t_{i}-Y_{0 b s_{i}} \mid * 100\right)}{Y_{o b s_{i}}}\right)}{N} \\
R^{2} \text { adjusted }=\left[1-\frac{\left(1-R^{2}\right) \times(n-1)}{n-k-1}\right] \\
E S=\sqrt{\frac{\sum_{i=1}^{N}\left(Y_{\left.o b s_{i}-Y_{e s t}-C\right)^{2}}\right.}{N}}
\end{gathered}
$$

where Yest $_{\mathrm{i}}$ is an estimated variable, Yobs $_{\mathrm{i}}$ is an observed variable, $\mathrm{Y}_{\text {est-C }}$ is a variable estimated by linear regression between the observed $\left(\right.$ Yobs $_{\mathrm{i}}$ ) and estimated (Yest ${ }_{i}$ ) variables, $\mathrm{N}$ is the number of years, $\mathrm{n}$ is the number of datapoints, and $\mathrm{k}$ is the number of independent variables in the regression.

We developed models that integrated two climatic variables at the same time with the data for fruit growth using a response surface analysis for the various combinations of meteorological elements and fruit-growth variables. We present only the best models that had a low MAPE and ES and an $R^{2}$ adj near 1, using SigmaPlot $11.0^{\circledR}$.

\section{RESULTS AND DISCUSSION}

The analysis of the influence of average rates of variation of the meteorological elements on the growth rates of fruit lychee indicated that a WD rate near $5 \mathrm{~mm} \mathrm{~d}^{-1}$ maximised FM, DM, LE, DI, and VO, suggesting that WD was important for full crop development. Similar results were reported by Aparecido et al. (2015) for the influence of climate on the development of coffee. PET and AET rates $>50$ $\mathrm{mm}$ and $\mathrm{DD}$ rate $>100^{\circ} \mathrm{C}$ days increased FM, DM, and VO and decreased LE and FN (Figure 1). These relationships are in accord with those reported by Oliveira et al. (2012) indicating that the accumulation of DD for eucalyptus increased FM and DM. 
The average rates should be integrated on a daily scale during the growth period of the fruit to enable the final phytotechnical estimates (Figure 1). We used adjusted logistic and Boltzmann models, however, for estimating the growth parameters of lychee fruit based on the meteorological conditions throughout the growing season. The accumulation of WD, PET, AET, and DD had sigmoidal relationships with all variables of fruit growth except FN. FN decreased with increasing WD, PET, AET, and DD.

All adjusted models were significant $(p<0.001)$, with low MAPE and ES and an $R^{2}$ adj $\square 1.0$, indicating that the growth of lychee fruit could be estimated using the variation of accumulated meteorological elements. For example, the logistic model that estimated FM from WD had a MAPE of $26.8 \%, R^{2}$ adj of 0.99 , and ES of $8.2 \mathrm{~g}$ (Figure 2.a). An error of $26.8 \%$ for FM represents $20 \mathrm{~g}$ (final value) $\pm 5.4 \mathrm{~g}$, a low error for a fruit. The adjusted models with higher accuracies were $\sum F M=f(D D)$, $\sum \mathrm{DM}=\mathrm{f}(\mathrm{DD}), \sum \mathrm{LE}=\mathrm{f}\left(\sum \mathrm{AET}\right), \sum \mathrm{DI}=\mathrm{f}\left(\sum \mathrm{AET}\right)$, $\sum \mathrm{VO}=\mathrm{f}\left(\sum \mathrm{WD}\right)$, and $\sum \mathrm{FN}=\mathrm{f}\left(\sum \mathrm{WD}\right)$, with MAPEs of $11.7,6.3,6.1,4.9,14.5$, and $7.6 \%$, respectively. The highest development (stabilisation) of FM, DM, LE, DI, and VO occurred for $\sum W D$ near $30 \mathrm{~mm}$, with $\sum$ PET and $\sum$ AET near $180 \mathrm{~mm}$, and DD near 750 ${ }^{\circ} \mathrm{C}$ day (Figures 2-5). The fruit can begin to mature after this stage (SILVA et al., 2013; MATARAZZO et al. 2013).

The models adjusted with parameter $\alpha$ indicated that the maximum final values of FM, DM, LE, DI, VO, and FN were approximately $21.8 \mathrm{~g}$,
$5.5 \mathrm{~g}, 38.6 \mathrm{~mm}, 35.5 \mathrm{~mm}, 18.6 \mathrm{~cm}^{3}$, and 92.4 fruits, respectively. The models adjusted with parameter $\gamma$ indicated that the efficiency of fruit development was dependent on climate. For example, each $1 \mathrm{~mm}$ of increase in $\sum \mathrm{WD}$ on average decreased FM by $0.29 \mathrm{~g}$ (Figure 2.a), DM by $0.34 \mathrm{~g}$ (Figure 2.b), LE by $0.09 \mathrm{~mm}$ (Figure 2.c), DI by $0.1 \mathrm{~mm}$ (Figure 2.c), and $\mathrm{VO}$ by $0.2 \mathrm{~cm}^{3}$.

We used a response surface analysis with adjustments of nonlinear models to lower MAPE and evaluate the integration of two meteorological elements in the estimates of fruit growth. The models were significant $(p<0.001)$ (Table 1) and highly accurate and precise; MAPE was $6.45 \%$ for VO based on $\sum W D$ and $\sum D D$. All phytotechnical variables except FN responded asymptotically to the environmental conditions (Figure 6). Knowing the influence of climate is essential, because the environment directly controls the physiology of fruit (SILVA et al., 2013).

$\sum W D$ promoted reductions of all phytotechnical variables, except for FN. DD was associated with increases for all phytotechnical variables of the fruits (Figure 1). These results were similar to those by Calzavara et al. (2000), who demonstrated that WD in oranges decreased the number of fruits, and by Magalhães Filho et al. (2008), who reported that WD decreased the formation of aerial biomass from working citrus rootstock due to a decrease in the photosynthetic capacity of the plant. 
TABLE 1- Selected models a) fresh matter FM, g; b) dry matter DM, g; c) fruit length LE, mm; d) fruit diameter DI, mm; e) fruit volume $\mathrm{VO}, \mathrm{cm}^{3} ;$ f) fruits number per cluster $\mathrm{FN}$, uni; according to environmental conditions.

\begin{tabular}{|c|c|c|}
\hline \multicolumn{2}{|c|}{ Parameters } & Models \\
\hline $\mathrm{MAPE}=$ & 5.26 & \multirow{3}{*}{ 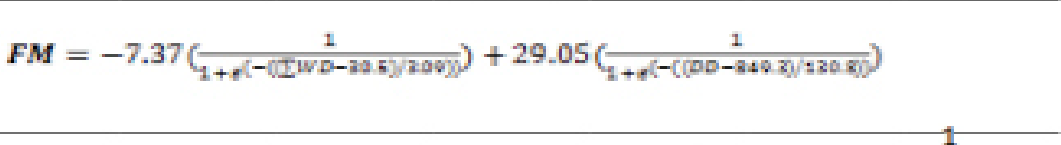 } \\
\hline $\mathrm{R}^{2}$ adj $=$ & 0.999 & \\
\hline $\mathrm{ES}=$ & 8.0 & \\
\hline $\mathrm{MAPE}=$ & 2.12 & \multirow{3}{*}{$D M=-0.037+0.000026 \Sigma W D+0.00040 \sum W D^{2}+6.29\left(\frac{1}{1+e^{\left(-\left(\frac{D D-720.9}{122.8}\right)\right.}}\right.$} \\
\hline $\mathrm{R}^{2}$ adj - & 0.999 & \\
\hline $\mathrm{ES}=$ & 3.58 & \\
\hline $\mathrm{MAPE}=$ & 1.22 & \multirow[t]{3}{*}{$L E=12.16+0.035 \sum A E T+5.96 \sum A E T^{2}+27.86\left(-e^{160.95}\right)$} \\
\hline $\mathrm{R}^{2}$ adj $=$ & 0.999 & \\
\hline $\mathrm{ES}=$ & 27.6 & \\
\hline MAPE $=$ & 2.39 & \multirow{3}{*}{$D I=0.955-0.0117 \Sigma W D+37.07\left(\frac{1}{\left.1+\theta^{\left(-\left(\frac{00-71.45}{285.2 \pi}\right)\right)}\right)}\right.$} \\
\hline $\mathrm{R}^{2}$ adj $=$ & 0.999 & \\
\hline $\mathrm{ES}=$ & 16.2 & \\
\hline $\mathrm{MAPE}=$ & 6.45 & \multirow{3}{*}{ 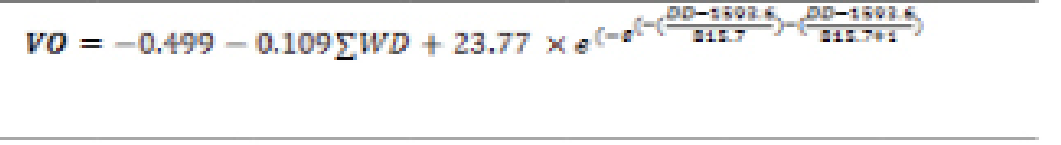 } \\
\hline $\mathrm{R}^{2}$ adj $=$ & 0.999 & \\
\hline $\mathrm{ES}-$ & 6.16 & \\
\hline $\begin{array}{l}\text { MAPE }= \\
\mathrm{R}^{2} \text { adj }=\end{array}$ & $\begin{array}{r}2.84 \\
0.999\end{array}$ & \multirow[t]{2}{*}{$F N=52.37-0.13 \Sigma A E T+12.6 \times \ln \Sigma W D-0.00045 \Sigma A E T^{2}-8.8 \times(\ln \Sigma$} \\
\hline $\mathrm{ES}=$ & 12.14 & \\
\hline
\end{tabular}



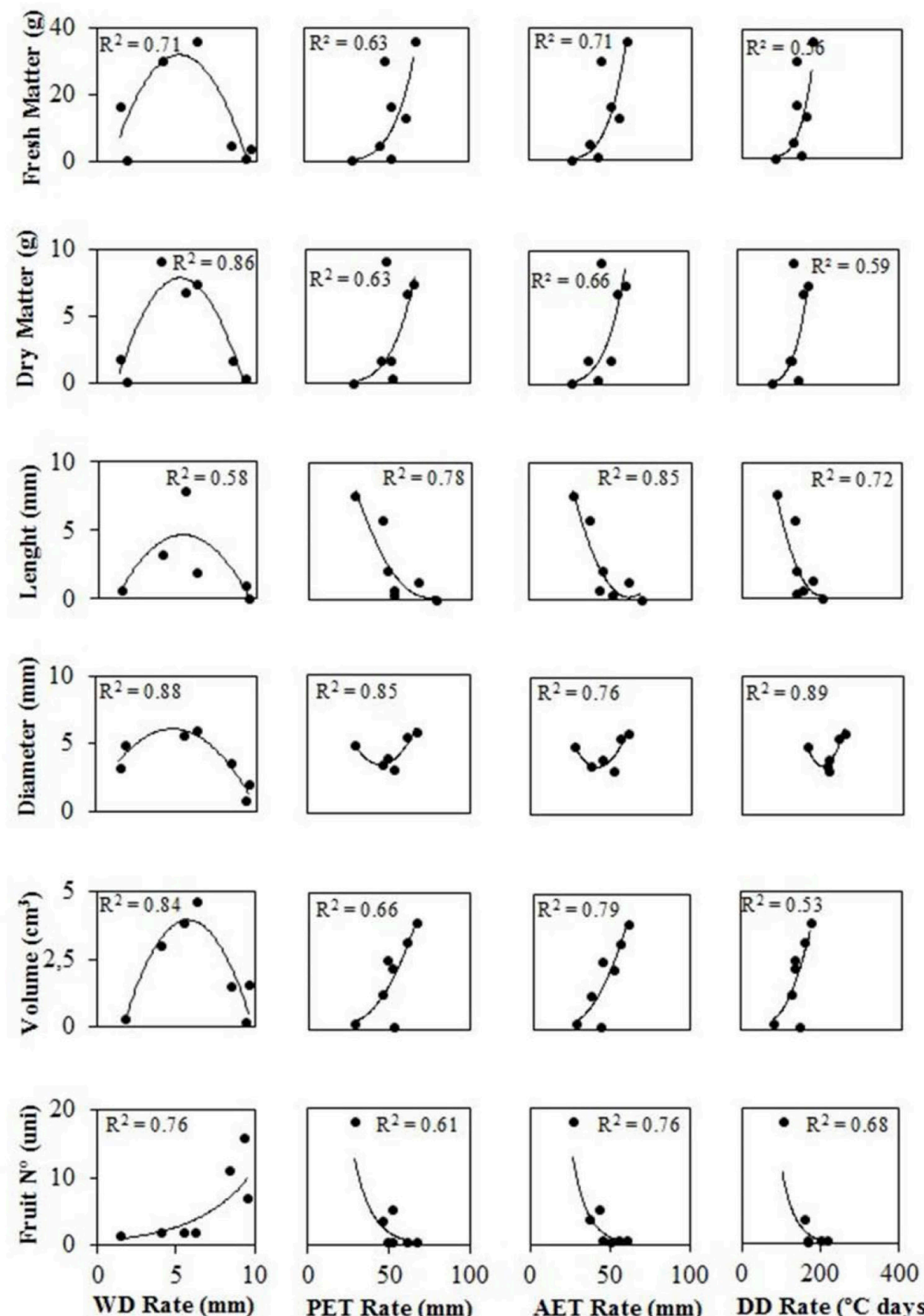

DD Rate $\left({ }^{\circ} \mathrm{C}\right.$ days)

FIGURE 1-Fruit fresh matter $(\mathrm{g})$, dry matter $(\mathrm{g})$, fruit length $(\mathrm{mm})$, fruit diameter $(\mathrm{mm})$, fruit volume $\left(\mathrm{cm}^{3}\right)$ and fruit number per cluster related to water deficit (WD, $\mathrm{mm}$ ), potential evapotranspiration (PET, $\mathrm{mm})$ and actual evapotranspiration (AET, $\mathrm{mm})$ and degree days $\left({ }^{\circ} \mathrm{C}\right.$ days) rate. 

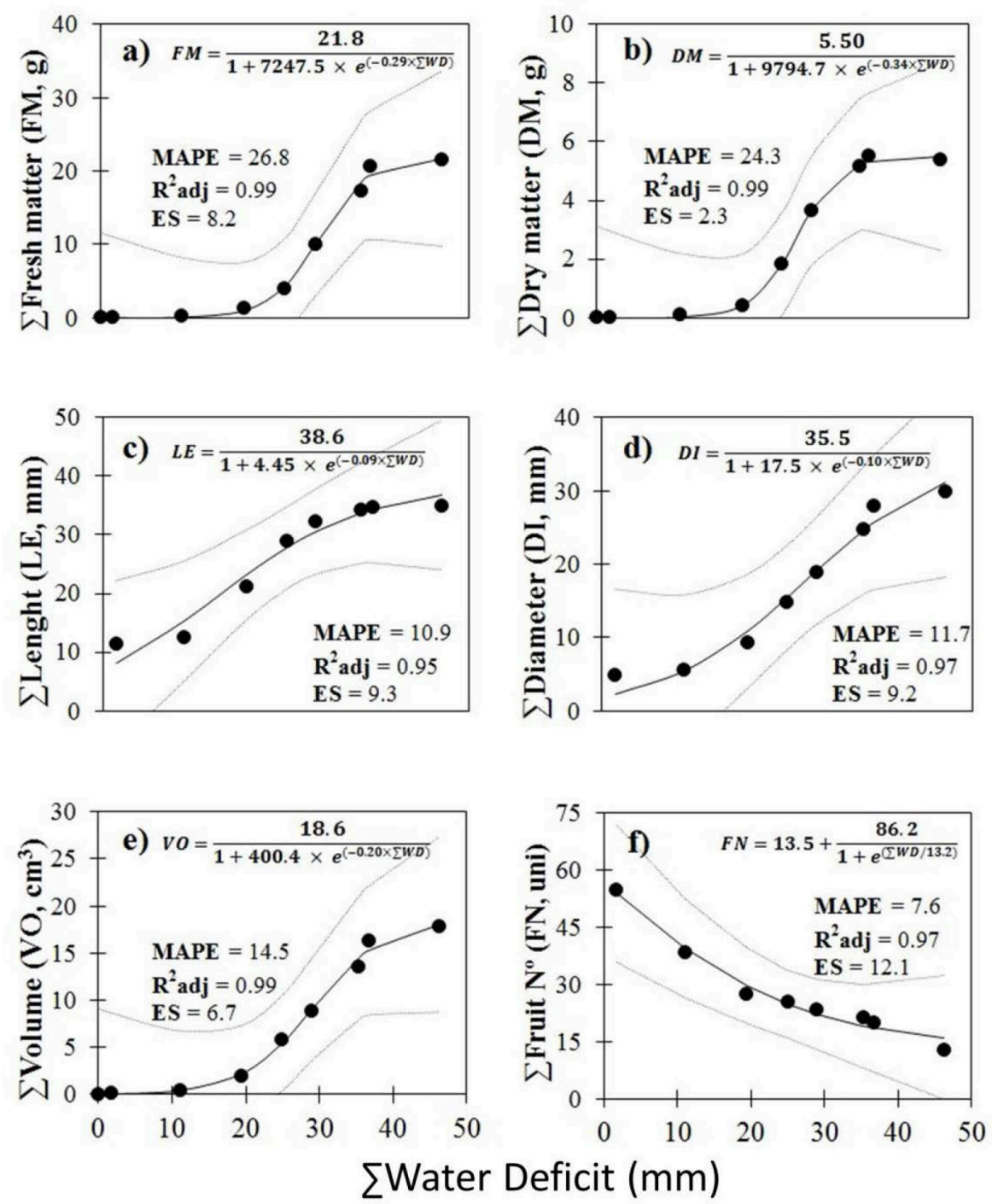

FIGURE 2- Lychee fruit development according to the summation of water deficit (WD, mm). a) fresh matter (FM, g); b) dry matter (DM, g); c) fruit length (LE, mm); d) fruit diameter (DI, mm); e) volume $\left(\mathrm{VO}, \mathrm{cm}^{3}\right)$; f) fruits number per cluster (FN, number). Points are observed values, estimated full line and the dashed the confidence interval (95\%). 

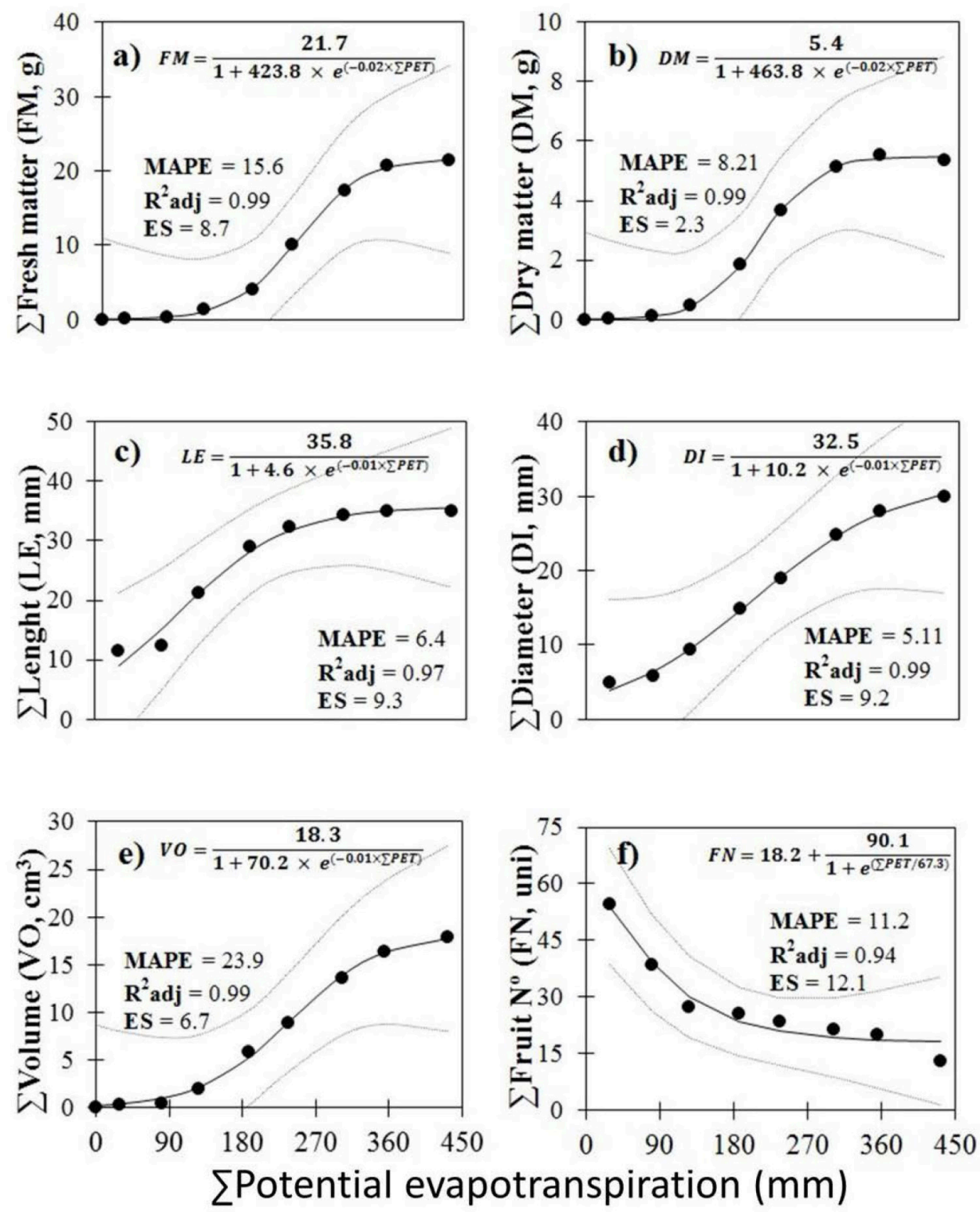

FIGURE 3- Lychee fruit development according to the summation of potential evapotranspiration (PET, $\mathrm{mm})$. a) fresh matter (FM, g); b) dry matter (DM, g); c) fruit length (LE, mm); d) fruit diameter $(\mathrm{DI}, \mathrm{mm}) ; \mathrm{e})$ fruit volume $\left(\mathrm{VO}, \mathrm{cm}^{3}\right) ; \mathrm{f}$ ) fruits number per cluster (FN, number). Points are observed values, estimated full line and the dashed the confidence interval $(95 \%)$. 

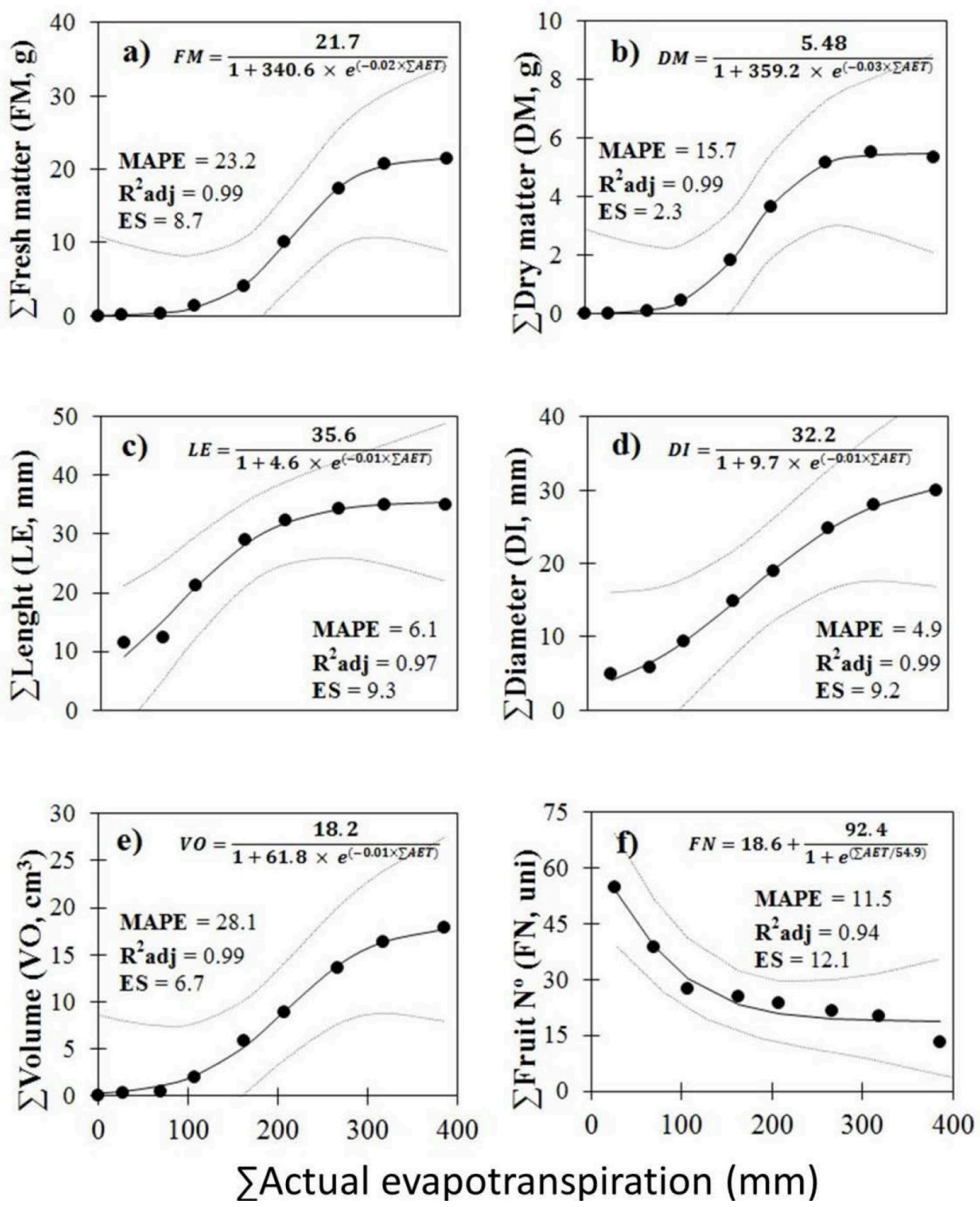

FIGURE 4- Lychee fruit development according to the summation of actual evapotranspiration (AET, mm). a) fresh matter (FM, g); b) dry matter (DM, g); c) (fruit length LE, mm); d) fruit diameter (DI, $\mathrm{mm})$; e) fruit volume (VO, $\left.\mathrm{cm}^{3}\right)$; f) fruits number per cluster (FN, number). Points are observed values, estimated full line and the dashed the confidence interval (95\%). 

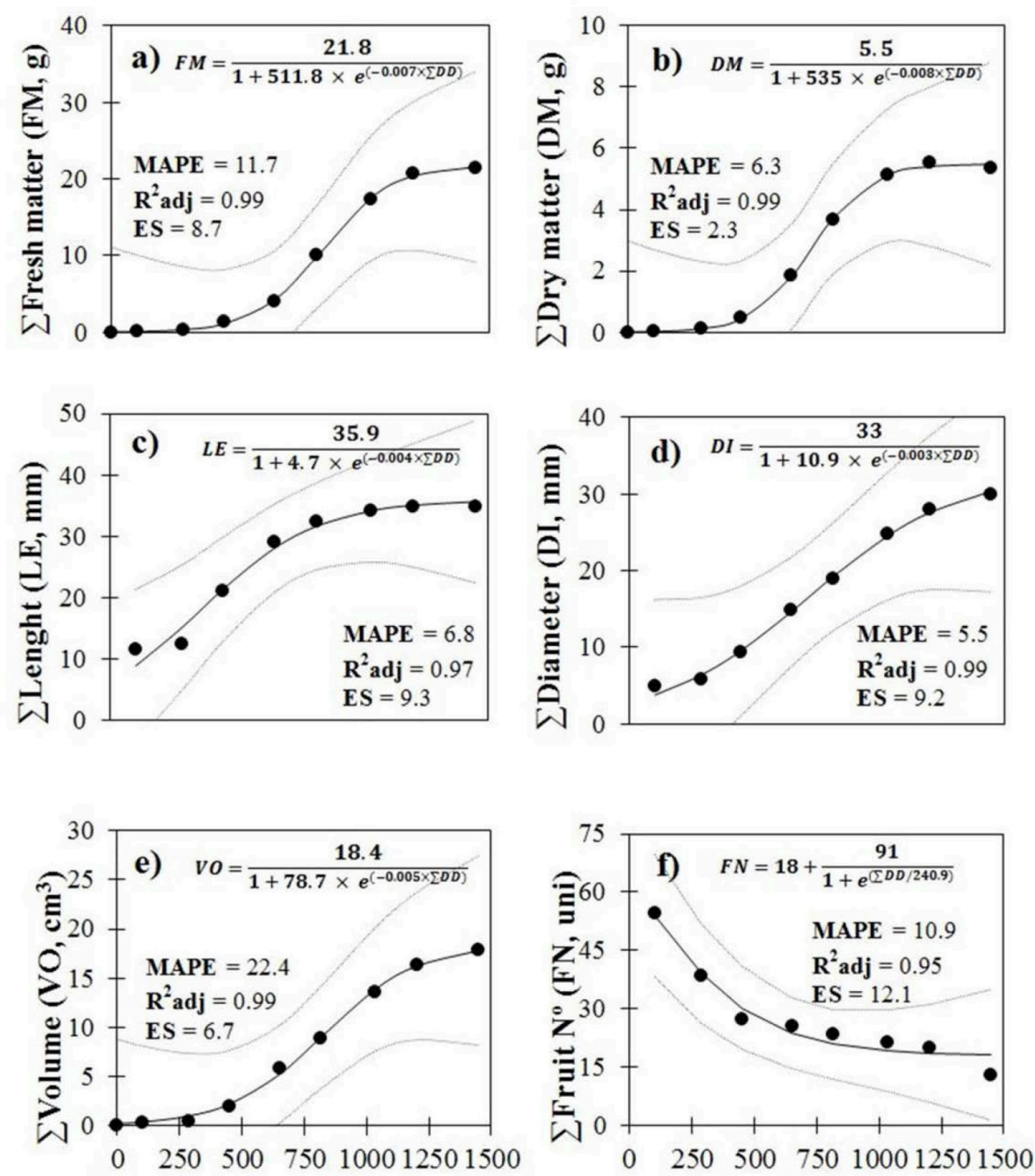

\section{¿Degree Days (으 days)}

FIGURE 5-Lychee fruit development according to the summation of degree days (DD, ${ }^{\circ} \mathrm{C}$ days); a) fresh matter (FM, g); b) dry matter (DM, g); c) fruit length (LE, mm); d) fruit diameter (DI, mm); e) fruit volume $\left.\left(\mathrm{VO}, \mathrm{cm}^{3}\right) ; \mathrm{f}\right)$ fruits number per cluster (FN, number). Points are observed values, estimated full line and the dashed the confidence interval (95\%). 

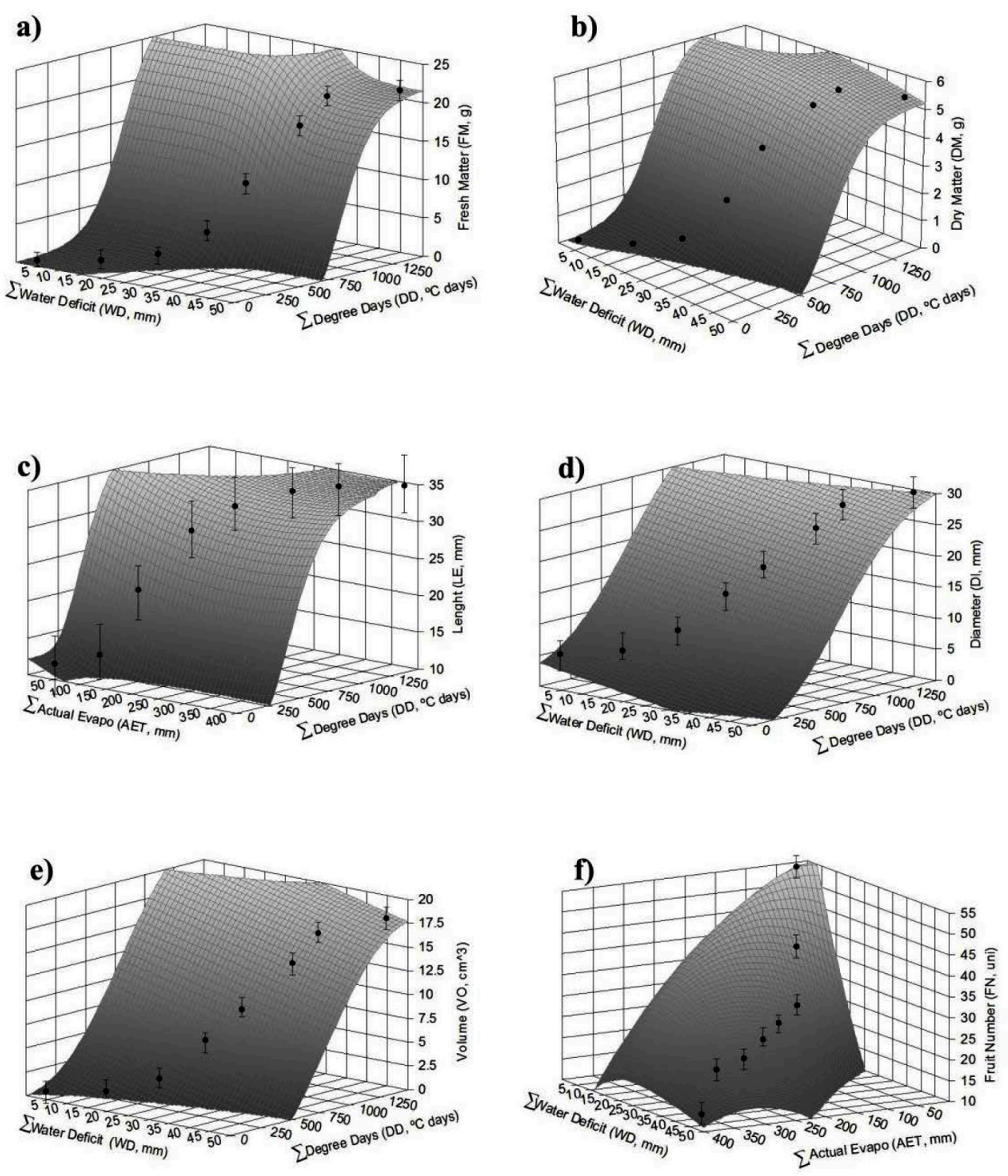

FIGURE 6- Phytotechnical variables, a) fresh matter (FM, g); b) dry matter (DM, g); c) fruit length (LE, $\mathrm{mm})$; d) fruit diameter (DI, $\mathrm{mm})$; e) fruit volume $\left(\mathrm{VO}, \mathrm{cm}^{3}\right)$; f) fruits number per cluster (FN, number); according to accumulation of water deficit, actual and potential evapotranpiration and degree days. 


\section{CONCLUSIONS}

The agrometeorological models accurately simulated the development of fresh matter, dry matter, fruit length, fruit diameter, fruit volume, and fruit number per cluster of "Bengal" lychee as functions of the climatic conditions. Rates of water deficit of $0.5 \mathrm{~mm} \mathrm{~d}^{-1}$, evapotranspiration $>50$ $\mathrm{mm}$, and degree days $>100{ }^{\circ} \mathrm{C}$ days promoted the development of the lychee fruits. The fruit number per cluster of the "Bengal" cultivar decreased with increases in the rates of degree days of $200{ }^{\circ} \mathrm{C}$ day, potential evapotranspiration of $50 \mathrm{~mm}$, and actual evapotranspiration of $50 \mathrm{~mm}$. The development of the lychee fruits stabilised for a $\sum$ water deficit near $30 \mathrm{~mm}$, Epotential evapotranspiration and $\sum$ actual evapotranspiration near $180 \mathrm{~mm}$, and $\sum$ degree days near $750{ }^{\circ} \mathrm{C}$ day.

\section{REFERENCES}

ALBUQUERQUE, A.H.P.; VIANA, T.V.A.; MARINHO, A.B.; SOUSA, G.G.; AZEVEDO, B.M. Irrigação e fertirrigação potássica na cultura da videira em condições semiáridas. Pesquisa Agropecuária Tropical, Goiânia, v.43, n.3, p.31521,2013

ALVES, R.R.; SALOMÃO, L.C.C.; SIQUEIRA, D.L.; CECON, P.R.; SILVA, D.F.P. Desenvolvimento do maracujá doce em Viçosa, Minas Gerais. Revista Ceres, Viçosa, MG, v.59, n.6, p.127-133, 2013.

APARECIDO, L.E.O; ROLIM, G.S.; SOUZA, P.S.Sensitivity of newly transplanted coffee plants to climatic conditions at altitudes of Minas Gerais, Brazil. Australian Journal of Crop Science, Melbourne, v.9, n.2, p.160-7, 2015.

AOAC - Association Of Official Analytical Chemists. Official methods of analysis of the association of the official analytical chemists. 17 th ed. Arlington, 2012.

BRIXNER, G.F.; SCHÖFFEL, E.R.; LAGO, I.; RADÜNZ, A.L.; Risco de geada e duração dos subperíodos fenológicos da 'Cabernet Sauvignon' na região da Campanha. Revista Brasileira de Engenharia Agrícola e Ambiental, Campina Grande, v.18, n.2, p.217-24, 2014.
CALZAVARA，S.A.; PEREIRA，O.C.N.; BERTONHA, A.; GONÇALVES, A.C.A.; Número de frutos de laranja em função da frequência de irrigação complementar. Acta Scientiarum, Maringá, v.22, p.1125-8, 2000.

CORNELL, J.A.; BERGER, R.D.Factors that influence the coefficient of determination in single linear and nonlinear models. Phytopathology, Palo Alto, v.77, p.63-70, 1987.

DEMBITSKY, V.M.; POOVARODOM, S.; LEONTOWICZ, H.; LEONTOWICZ, M.; VEARASILP, S. The multiple nutrition properties of some exotic fruits: Biological activity and active metabolites. Food Research International, Amsterdam, v.44, p.1671-701, 2011.

GAZULA, A.; KLEINHENZ, M.D.; STREETER, J.G.; MILLER, A.R. Temperature and cultivar effects on anthocyanin and chlorophyll b concentrations in three related Lollo Rosso lettuce cultivars. HortScience, Alexandria, v.40, p.1731-3, 2005.

\section{HIEKE et al.2002 consta na p.3 linha 3}

KUMAR, S.; MISHRA, B.B.; SAXENA, S.; BANDYOPADHYAY, N.; MORE, V. Inhibition of pericarp browning and shelf life extension of litchi by combination dip treatment and radiation processing. Food Chemistry, New York, v.131, p.1223-32, 2012.

KUMAR, A.; SHARMA, P.; AMBRAMMAL, S.K. Climatic effects on food grain productivity in India: a crop wise analysis. Journal of Studies in Dynamics and Change, Uttarakhand v.1, p.38-48, 2014.

LASDON, L.S.; WAREN, A.D. GRG2 user's guide. Austin: University of Texas, 1982.

LIMA, R.A.Z.; ABREU C.M.P; ASMAR S.A.; CORRÊA A.D.e SANTOS C.D. Embalagens e recobrimento em lichias (Litchi chinensis Sonn.) armazenadas sob condições não controladas.Ciência e Agrotecnologia, Lavras, v.34, n.4, p.914-921, 2010 .

MAGALHAES FILHO, J.R.; AMARAL, L.R.; MACHADO, D.F.S.P.; MEDINA, C.L. Deficiência hídrica, trocas gasosas e crescimento de raízes em laranjeira Valência sobre dois tipos de porta-enxertos. Bragantia, Campinas, v.67, n.1, p.75-82, 2008. 
MARTINS, A.B.G. Lichia. Revista Brasileira de Fruticultura, Jaboticabal, v.27, n.3, p.349-51, 2005.

MATARAZZO, P.H.M.; SIQUEIRA, D.L.; SALOMÃO, L.C.C.; SILVA, D.F.P.; CECON, P.R. Desenvolvimento dos frutos de lulo (solanum quitoense lam), em Viçosa-Mg. Revista Brasileira de Fruticultura, Jaboticabal, v.35, n.1, p.131-42, 2013.

MENZEL, C.M.; PAXTON, B.F. The effect of temperature on growth and dry matter production of lychee seedlings. Scientia Horticulturae, Amsterdam, v.26, p.17-23, 1985.

OLIVEIRA, A.S.; STEIDLE NETO, A.J.; RIBEIRO, A.; RASCON, N.JR.L., RODY, Y.P.; ALMEIDA, A.Q. Determinação do tempo térmico para o desenvolvimento de mudas de eucalipto na fase de enraizamento. Revista Brasileira de Engenharia Agrícola e Ambiental, Campina Grande, v.16, n.11, p.1223-8, 2014.

OLIVEIRA, R.A.; SANTOS, R.S.; RIBEIRO, A.; ZOLNIER, S.; BARBOSA, M.H.P. Estimativa da produtividade da cana-de-açúcar para as principais regiões produtoras de Minas Gerais usando-se o método ZAEI. Revista Brasileira Engenharia Agrícola e Ambiental, Campina Grande, v.16, n.5, pp.549-57, 2012.

PANDEY, N.; JOSHII, S.K.; SINGH, C.P.; KUMAR, S.; RAJPUT, S.; KHANGAL, R.K. Enhancing shelf life of litchi (Litchi chinensis) fruit through integrated approach of surface coating and gamma irradiation. Radiation Physics And Chemistry, v.85, p.197203, 2013.

PEREIRA, L.S.; MITRA, S.K. Studies on fruit growth and development of litchi cultivars Bombai, China, Deshi and Early Large Red. Horticultural Journal, Mohanpu, v.17, n.2 p.115-124, 2004.

PEIXOTO, C.P.; CERQUEIRA, E.C.; SOARES FILHO, W.S.; CASTRO NETO, M.T.DE; LEDO, C.A.S. Análise de crescimento de diferentes genótipos de citros cultivados sob déficit hídrico. Revista Brasileira de Fruticultura, Jaboticabal, v.28, n.3, p.439-43, 2006.
QUEIROZ, E.R.; ABREU, C.M.P.; OLIVEIRA, K.S. Constituintes químicos das frações de lichia in natura e submetidas à secagem: potencial nutricional dos subprodutos. Revista Brasileira de Fruticultura, Jaboticabal, v.34, n.4, p.1174-9, 2012.

REUCK, K.D.; SIVAKUMAR, D.; KORSTEN, L. Integrated application of 1-methylcyclopropene and modified atmosphere. Postharvest Biology and Technology, Pretoria, v.52, p.71-7, 2009.

ROLIM, G.S.; APARECIDO, L.E.O. Camargo, Köppen and Thornthwaite climate classification systems in defining climatical regions of the state of São Paulo, Brazil. International Journal of Climatology, New York, v.36, n.2, p.636-43, 2015.

SALOMÃO, L.C.C; SIQUEIRA, D.L; PEREIRA, M.E.C. Desenvolvimento do fruto da Lichieira (Litchi chinensis Sonn.) 'Bengal'. Revista Brasileira de Fruticultura, Jaboticabal, v.28, n.1, p.11-3, 2006.

SANTOS, C.E.M.; SILVA, J.O.C.; CAVATTE, R.P.Q.; SALOMÃO, L.C.C.; BRUCKNER, C.H.Raleio de Frutos em Lichieira 'Bengal'. Revista Brasileira de Fruticultura, Jaboticabal, v.31, n.2, p.588-92, 2009.

SANTOS, R.F.; CARLESSO, R. Déficit hídrico e os processos morfológico e fisiológico das plantas. Revista Brasileira Engenharia Agrícola e Ambiental, Campina Grande, v.2, n.3, p.287-94, 1998.

SILVA, D.F.P.; SILVA, J.O.C.E.; MATIAS, R.G.P.; RIBEIRO, M.R.BRUCKNER, C.H. Growth curve and respiratory pattern of genotypes of peach fruit in subtropical region. Revista Brasileira de Fruticultura, Jaboticabal, v.35, n.2, p.642-9, 2013.

SOMBOONKAEW, N.; TERRY, L.A. Altered physiology and biochemistry of imported litchi fruit held under different vapor pressure deficits. Journal of Agricultural and Food Chemistry, Birmingham, v.58, p.6209-18, 2010.

SOUZA, A. V.; VIEITES, R. L.; KOHATSU, D. S.; LIMA, G. P. P. Tratamento térmico na manutenção da coloração de lichias. Rev. Bras. Frutic. v.32, n.1, p.067-073, 2010. 
QI, S.; HUANG, H.; HUANG, J.; WANG, Q.; WEI, Q. Lychee (Litchi chinensis Sonn.) seed water extract as potential antioxidant and anti-obese natural additive in meat products. Food Control, New York, v.50, p.195-201, 2015.

THORNTHWAITE, C.W. An approach towards a rational classification of climate. Geographical Review, New York, v.38, p.55-94, 1948.

THORNTHWAITE, C.W.; MATHER, R.J. The water balance. New Jersey: Drexel Institute of Technology, 1955. v.8.

WAGNER, M.V.; JADOSKI, S.O.; LIMA, A.S.; MAGGI, M.F.; POTT, C.A.; SUCHORONCZEK, A.Avaliação do ciclo fenológico da cultura do milho em função da soma térmica em Guarapuava, Sul do
Brasil. Revista Brasileira de Tecnologia Aplicada nas Ciências Agrárias, Guarapuava, v.4, n.1, p.13549, 2011.

WALTER, L.C.; STRECK, N.A.; ROSA, H.T.; FERRAZ, S.E.T.; CERA, J.C. Mudanças climáticas e seus efeitos no rendimento de arroz irrigado no Rio Grande do Sul. Pesquisa Agropecuária Brasileira, Brasília, DF, v.49, n.12, p.915-24, 2014.

WEI, Y.Z.; ZHANG, H.N.; LI, W.C.; XIE, J.H; WANG, Y.C; LIU, L.Q.; SHI, S.Y.Phenological growth stages of lychee (Litchi chinensis Sonn.) using theextended BBCH-scaleY. Scientia Horticulturae, Zhanjiang, v.161, p.273-277, 2013. 